International Journal of Power Electronics and Drive Systems (IJPEDS)

Vol. 12, No. 4, December 2021, pp. 2160 2168

ISSN: 2088-8694, DOI: 10.11591/ijpeds.v12.i4.pp2160-2168

\title{
Harnessing wind and solar PV system to build hybrid power system
}

\author{
S. S. Saswat ${ }^{1}$, Suman Patra ${ }^{2}$, Debani Prasad Mishra ${ }^{3}$, Surender Reddy Salkuti ${ }^{4}$, Rudra Narayan \\ Senapati $^{5}$ \\ ${ }^{1-3}$ Department of Electrical and Electronics Engineering, IIIT Bhubaneswar, Odisha, India \\ ${ }^{4}$ Department of Railroad and Electrical Engineering, Woosong University, Daejeon, Republic of Korea \\ ${ }^{5}$ Department Electrical Engineering, KIIT Deemed to be University, Odisha, India
}

\section{Article Info \\ Article history: \\ Received Jan 17, 2021 \\ Revised Sep 23, 2021 \\ Accepted Aug 3, 2021}

\section{Keywords:}

Battery

Converter

Hybrid power system

Photovoltaic cell

Wind energy

\begin{abstract}
Electricity is the most important consideration for individual needs. Natural crossover power architecture using photovoltaic and wind is presented in this study, together with a Cuk direct current-direct current (DC-DC) converter, third phase inverter, and an inductors capacitors (LC) filter. Due to its natural disposal and availability in India, wind power and photovoltaics are ideal for the hybrid system. Hybrid power structures, on the other hand, reduce the risk of damage to equipment in sustainable stock storage since they have a higher electrical output. MATLAB Simulink was used to demonstrate this hybrid application. Before connecting the entire DC voltage frame with the main lattice of the power frame, blocks such as the wind model, PV model, Cuk converter, inverter, and LC channel are built individually. Information limitations for participating in varying levels of irradiance and variations in wind speed. The results show that the hybrid system has a considerably more reliable standard in terms of energy efficiency than an independent framework. Furthermore, the hybrid system's Cuk DC-DC converter, threephase standard-based inverter, and LC channel can minimise power switching power.
\end{abstract}

This is an open access article under the CC BY-SA license.

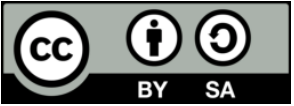

\section{Corresponding Author:}

Surender Reddy Salkuti

Department of Railroad and Electrical Engineering

Woosong University

17-2, Jayang-Dong, Dong-Gu, Daejeon-34606, Republic of Korea

Email: surender@wsu.ac.kr

\section{INTRODUCTION}

When it comes to daily life, we rely on electricity a great deal. Solar and wind electricity are readily available under the right conditions. One of the world's most powerful hybrid power systems using PV as well as wind energy [1]. Importance of electricity in daily life. The lazy end of cultural assets and reliance on unconventional resources in the near future [2]. PSMG's work with flexible rotating steps without the use of a gearbox, and outdoor entertainment. It has extremely high performance [3]. The total used circuit for highperformance, low-effort, and large-scale DC/DC product transformation is proposed to determine the geographies on the edge of the power structure associated with the PV grid [4]. Alternatively, the method is to use a multi-input inverter to connect more PV, air-fuel sources to DC transport, rather than connecting various inverters in the transport of the alternating current (AC) frame [5], [6], to improve the crossover $\mathrm{PV} /$ wind power structure and thus reduces costs. Development and redesign of a specific hybrid power framework associated with a network are provided with a high-power point tracking (MPPT) tracking 
capacity from a single framework [7]. The photovoltaics (PV) system is introduced by incorporating PV cell modeling, DC-DC topology conversion, and high-power point tracking methods [8]. Effects of lifting and dragging on translation devices and continuous robust operation of the horizontal axis and vertical axis currently in operation [9]. Existing methods for using electronic power technology to improve the performance of wind turbines in power systems to meet basic connectivity requirements [10].

A new system is proposed to track the point of permanent magnetic field energy conversion systems. This process searches for large relationships of the high-energy tracking system and controls the system according to these relationships [11]. On a conventional flexible generator, to evaluate the usual turbine generator framework. Multiple-post permanant magnet is the model of choice for this type of coordinated generator. Since it does not have a current Rotor and can be used without a gearbox, it offers greater performance due to higher production and fewer maintenance. This reduces nacelle weight and expenses. [12]. DC-DC help converter contains equivalent viable help converters and utilizations a 180-degree coordinated reconciliation methodology that animates the trade framework. The dc commitments to the mass data converter associated with the data are a $45 \mathrm{~V} / 6.5 \mathrm{~kW}$ force unit device and a $50 \mathrm{~V}$ photovoltaic module, which is shown utilizing a mass of MATLAB/Simulink [13]. Investigating the potential for power supply from a sunlight based breeze half breed framework to a distant area found independently from Ethiopia's primary power network [14].

A possible model is to be used in a hybrid solar-wind power system (HSWPS), which is given a single-pivot or hub-sun-oriented global positioning position [15]. A good system model for planning hybrid solar-wind systems that use battery banks to determine the appropriate framework structures and to ensure that the annual cost of the frameworks is limited while achieving the much-needed energy supply (LPSP) losses [16]. Experimental measurement models are total current cost, sustainable feature, and recovery time. Due to the pre-determined amount of investigation of the content of RES in traveler activities and the lack of intensive shelter courses, which requires offices with a certain level of comfort [17]. A potential answer for independent force age is to utilize a hybrid energy system corresponding with some hydrogen energy stockpiling [18]. Distributed power generation systems (DPGSs) because of environmentally friendly power sources experience a huge advancement around the world [19]. Solar PV energy has seen twofold digit development in the previous decade [20]. To incorporate an ideal relative integrator-subsidiary regulator for recurrence guideline in a disconnected microgrid power system based on sustainable age [21].

Stand-alone hybrid renewable energy system (SHRES) as a choice as opposed to oil based good based generators [22]. To calculate the best size of the evolutionarily stable strategy (ESS), PV, and diesel generator in a boat power system to restrict $\mathrm{CO}_{2}$ surge, fuel cost, and hypothesis cost [23]. To relate generators to the electrical framework using the AC transport with trackers [24]. Geology collected the most outrageous power using multi-input help converters for cream energy [25]. The plan and control of an autonomous hybrid solar-wind system (AHSWS) controlled scattered age framework giving to a $3 \phi-4$ wire framework [26]. The diminishing of expertise effectuated by the unreplenishable energy determination in view of the plunge of oil subordinates has made a substitute necessity for maintainable force sources to expect an essential part in giving power at a greater extension. [27]. A promise to the issue of controlling responsive powers and voltages in an electrical association [28]. The improvement of power quality (PQ) using power module and cushy based controller [29].

Several papers have been proposed by many authors but none have achieved $100 \%$ accuracy so far. This paper attempted to introduce a hybrid system model that combines cost and flexibility identification of system performance. Variation of decision, objective tasks, and issues are considered for this model. Variety of measurement and performance work best using a simple process to perform the task depending on the objective function under the constraints. The terms of operation of the hybrid wind/PV power generation system are briefly discussed and how they can be used in the power electronics sector.

\section{RESEARCH METHOD}

The execution is done by using MATLAB/Simulink programming. The critical squares are arranged in MATLAB as the breeze energy structure is mimicked through the application library in the sim power system tool stash. The solar-based PV framework and MPPT (greatest force point following) computation are reenacted using a sim power framework and by and large used Simulink blocks. The inverter circuit is mimicked using the force equipment library. The force framework and grid are recreated using a sim power system device compartment. The normal coupling point is recreated for synchronization of twist/close by planetary gathering to central power system lattice. To simulate the limitless transport and LC channel, a sim power structure apparatus compartment is used to simulate the boundless transport. To complete this section, MATLAB/Simulink programming is used to create a half-and-half force system setup, a wind energy 
structure plan, a sun-oriented PV-based system, battery-powered energy system, and DC-to-DC converter subsystem design.

Figure 1 depicts the broadcast diagram to trace the appropriate power structure of the hybrid. With a definitive objective of lessening the expense of a full life cycle, roundabout advancement procedures are utilized. It is utilized as an extremely prudent and effective timetable of different sorts of sustainable generators with diesel and battery reinforcement, good burden balance, accessibility of assets and so on the battery is charged and assuming the heap surpasses the inexhaustible force, it is released. An hourly working technique for different half and half changes is controlled by the non-direct force utilization of deficient ability to meet the heap. The utilization of sustainable power obstructions ought to be made quite far. To lessen yearly working expenses, the compelling utilization of an effective PV/solar wind plan is required.

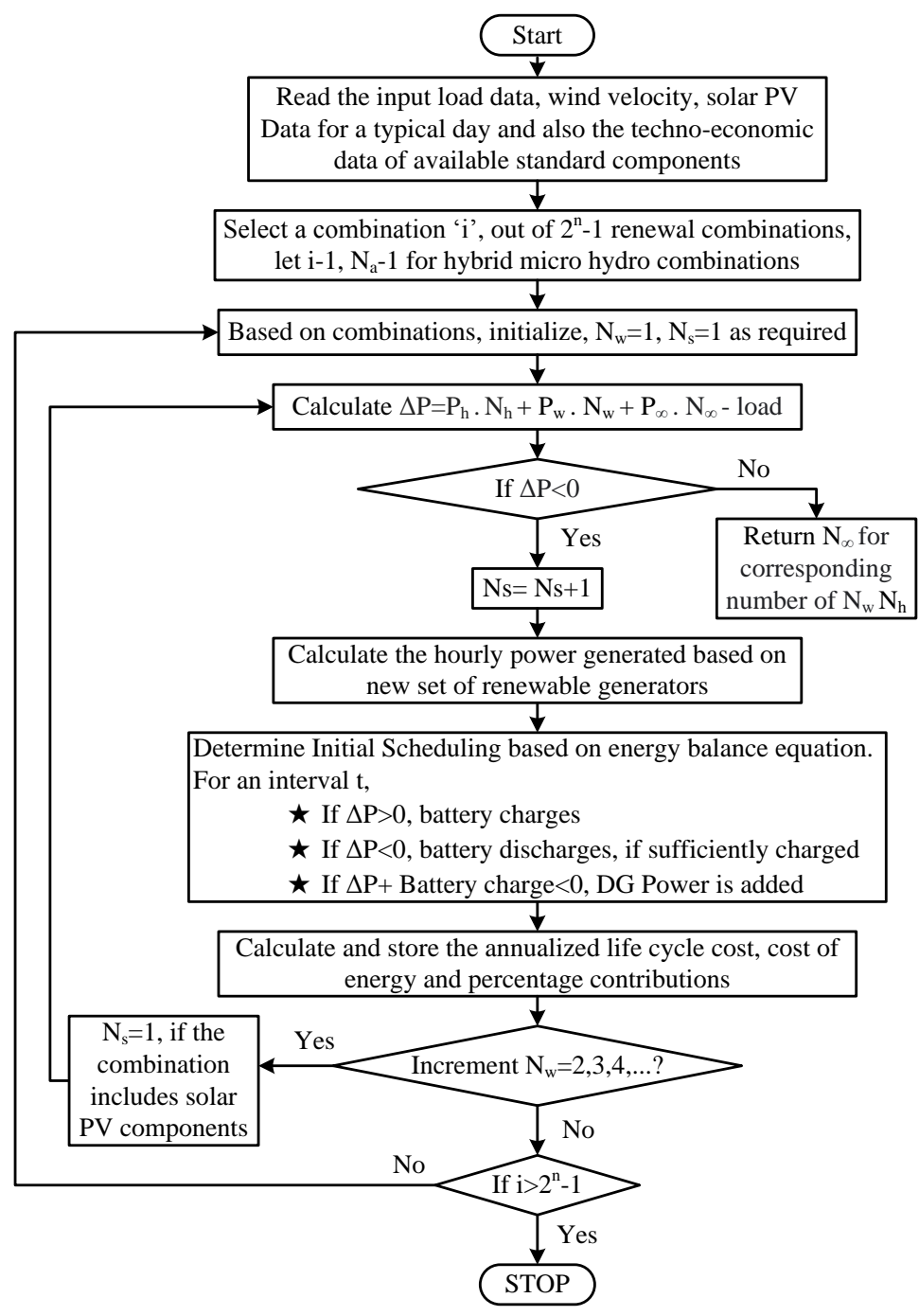

Figure 1. Flow chart for finding optimal hybrid power system

The total power generated by this frame can be provided as an addition to the power generated by the solar PV board and the power generated by the wind turbine [30]. This can be expressed by,

$$
P_{T}=\left(N_{W} P_{W}\right)+\left(N_{S} P_{S}\right)
$$

where $P_{T}$ is the total power generated, $P_{W}$ is the power generated by wind turbines, $P_{S}$ is the power generated by solar panels, $N_{W}$ is the number of wind turbines, and $N_{S}$ is the number of solar panels. The power produced by the wind energy is expressed as [30], 


$$
P_{W}=\frac{1}{2} \rho A_{W} V^{3}
$$

Where $P_{W}$ is wind power in watts (W), $\rho$ is the air density in $\mathrm{kg} / \mathrm{m}^{3}, A_{W}$ is the swept area by air in $\mathrm{m}^{2}, \mathrm{~V}$ is the wind speed in meters per second $(\mathrm{m} / \mathrm{s})$. The solar PV power can be calculated by [30],

$$
P_{S}=G(t) A_{s} \eta_{p v}
$$

Where $G(t)$ is the isolation at time $\mathrm{t}\left(\mathrm{kW} / \mathrm{m}^{2}\right), A_{s}$ is the area of a single PV panel $\left(\mathrm{m}^{2}\right)$, and $\eta_{p v}$ is the overall efficiency of PV panels and DC/DC converters. The overall efficiency is given by [30],

$$
\eta_{p v}=H \times P R
$$

Where $\mathrm{H}$ is the annual average solar radiation on tilted panels, PR is the performance ratio, which is the coefficient for losses.

The schematic of the hybrid PV/wind distributed power generation system is depicted in Figure 2, which contains 2 incorporated assistant inverters and completely associates the DC/AC inverter. DC power sources and are the elements of the PV group and the proper wind turbine, separately. Control the plot by working out the MPPT appropriate for power transformation Q1, Q2, Q3, Q4 it is feasible to get the most extreme force from just two sources or this time. DC power transmission control and power supply data is performed utilizing a DC interface capacitor, for example, power support, and a DC/AC inverter. The inverter changes the force dissemination of the casing, which is the reason by expanding or diminishing the AC power remembered for the utilization line contingent upon the DC transport limit. Synchronization of the utilization line is finished utilizing a phase-lock loop (PLL), which gives a sinusoidal reference sign to the sinusoidal PWM (SPWM) exchanging inverter control.

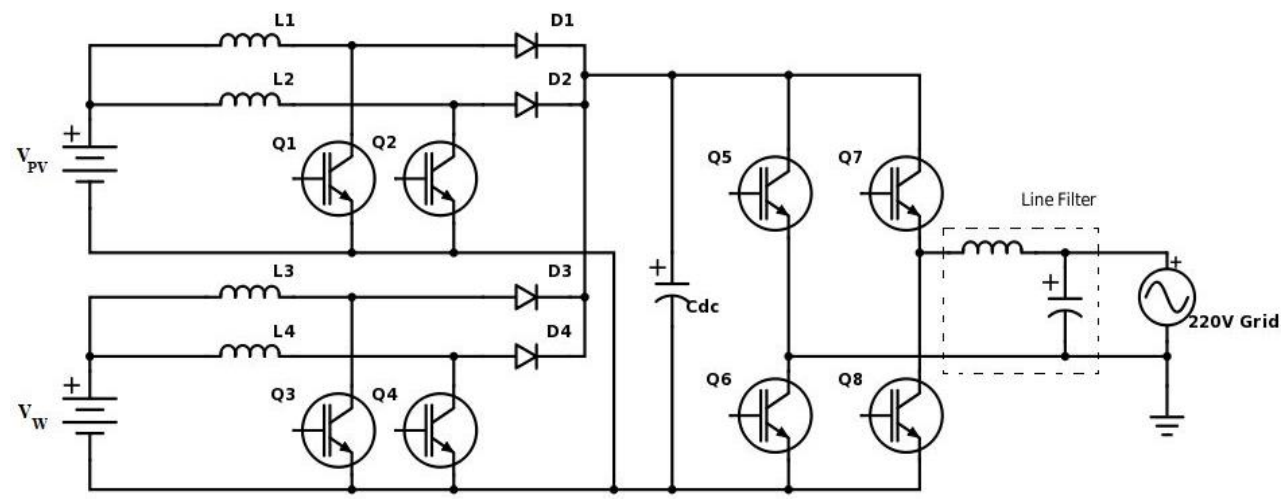

Figure 2. Simplified schematic of the hybrid PV/Wind distributed power generation system

PV Array show module is developed utilizing numerous designs or equal PV cells. Each PV cell is comprised of a PN crossing point semiconductor, which when seeing light turns into a wellspring of electrical course through the photovoltaic impact. A wind turbine changes over wind power into mechanical force, which then, at that point initiates a generator to produce electricity. The mechanical force of delivered by the wind turbine is given by [31],

$$
\begin{aligned}
& P_{m}=\frac{1}{2} \rho \pi R^{2} V^{3} C_{p}(\lambda, \beta) \\
& C_{p}(\lambda, \beta)=0.5176\left(\frac{116}{\lambda_{1}}-0.4 \beta-5\right) e^{-\left(\frac{21}{\lambda_{1}}\right)}+0.0068 \lambda \\
& \lambda=\frac{\omega_{m} R}{V_{w}} \\
& \frac{1}{\lambda_{1}}=\frac{1}{(\lambda+0.05 \beta)}-\frac{0.035}{\left(\beta^{3}+1\right)}
\end{aligned}
$$


Where $\rho$ the density of wind $(\mathrm{kg} / \mathrm{m} 3), \mathrm{R}$ is the radius $(\mathrm{m})$ of the wind-blown area, $\mathrm{V}$ is wind speed $(\mathrm{m} / \mathrm{s}), C_{p}$ is the turbine power coefficient [32].

Permanent magnet synchronous generator: with the continuation of electricity, the use of PMSGs has become a way of bending over large age structures of wind power. PMSG can operate at rotating speeds without the use of a gearbox, does not require external distraction, and has high efficiency [12], making it more suitable for hybrid-powered structures. Interleaved boost converter: connected cell-converted cell (IBC) cell is made up of at least partially converted converters, measured using an integration strategy until each button operates in the same switching mode than the switching phase $180^{\circ}$ [13].

\section{SIMULATION AND RESULTS}

The power station is classified and modified using the Power Systems Library from Simulink. To make this situation more imaginative, different time measures must be indicated in advance. The Simulink model for the whole framework is shown in Figure 3. Repeat with the previous different sizes and rotation frequency of the whole converter is assumed to depend on the total number of basic grid frequency of $60 \mathrm{~Hz}$, thereby minimizing recreational errors. The duration of the power domain is set at $5.0505 \mathrm{e}-6 \mathrm{~s}(1 /(3300 * 60$ $\mathrm{Hz}$ )), and the control time step, used for test and calculation measures, is set at $5.0505 \mathrm{e}-6$ seconds (most of the time the power of the domain time). To make the leisure time adequate and accurate, the maximum switching time is taken $(1980 \mathrm{~Hz})$, and in those large capacitors and inductors should be used. In real applications, the frequency of switching can be extended to several times this, thus reducing the size of the inductors and capacitors of the frame.

Table 1 represents the solar array module parameters and their corresponding values or results found during simulation. Table 2 represents the wind turbine PMSG parameters and their corresponding values or results found during simulation. Table 3 presents the power electronics systems parameters. The simulation results were also compared to the performance parameters.

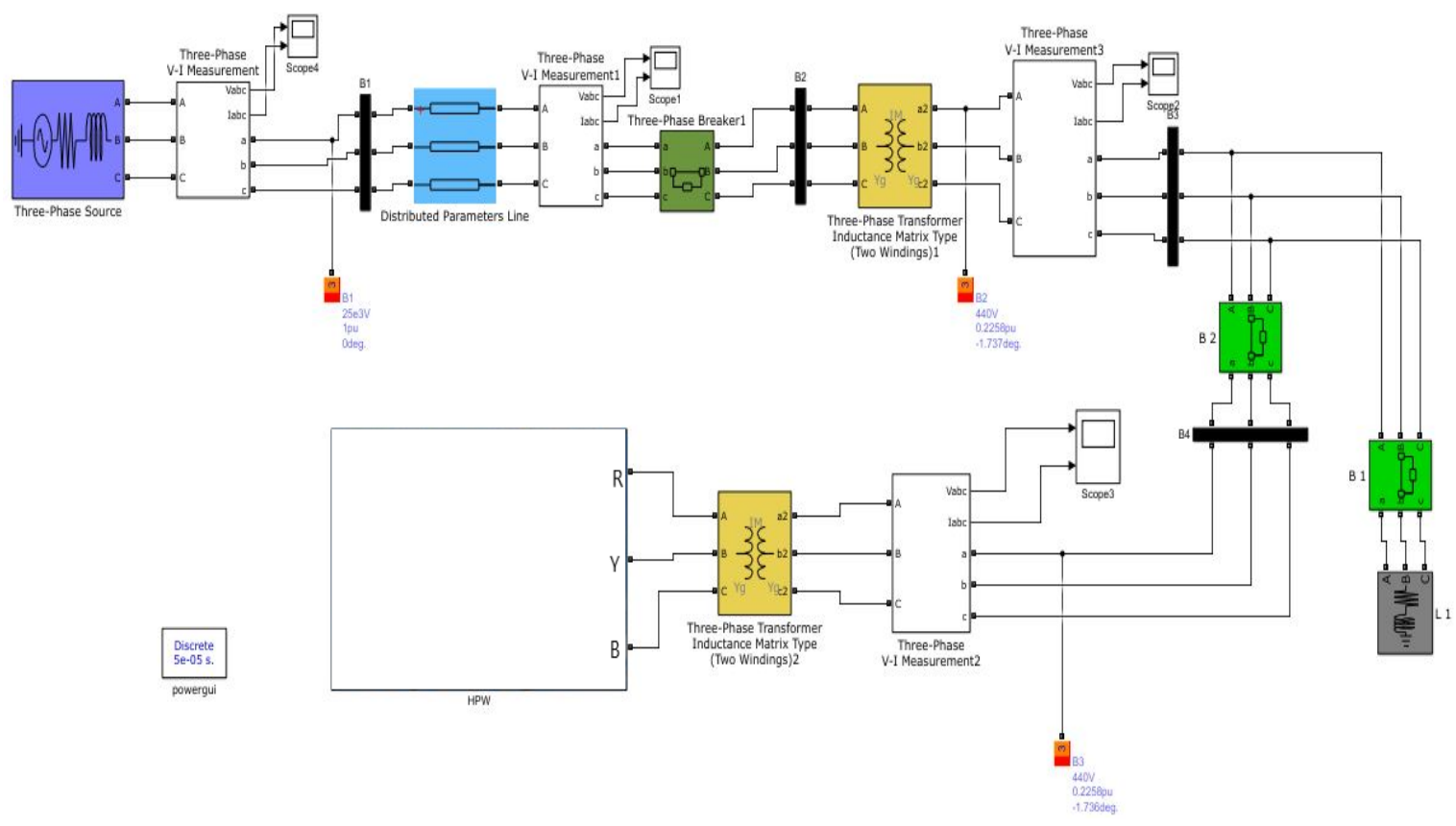

Figure 3. Simulink model of the PV/wind hybrid distributed generation power system

Table 1. Solar array module parameters

\begin{tabular}{lc}
\hline \multicolumn{1}{c}{ Parameter } & Value \\
\hline Rated Module output power, $\mathrm{P}_{\mathrm{MOD}}$ & $260 \mathrm{~W}$ \\
Short Circuit Current, I $\mathrm{SC}$ & $8.99 \mathrm{~A}$ \\
Open Circuit Voltage, $\mathrm{V}_{\mathrm{OC}}$ & $37.8 \mathrm{~V}$ \\
Voltage at Maximum Power, $\mathrm{V}_{\mathrm{MP}}$ & $30.7 \mathrm{~V}$ \\
Current at Maximum Power, $\mathrm{I}_{\mathrm{MP}}$ & $8.48 \mathrm{~A}$ \\
Number of cells in series, $\mathrm{N}_{\mathrm{S}}$ & 60 \\
Number of modules in series, $\mathrm{N}_{\mathrm{M}}$ & 5 \\
\hline
\end{tabular}

Int J Pow Elec \& Dri Syst, Vol. 12, No. 4, December 2021 : 2160 - 2168 
Table 2. Wind turbine PMSG parameters

\begin{tabular}{lc}
\hline \multicolumn{1}{c}{ Parameter } & Value \\
\hline Rated Output Power, $\mathrm{P}_{\mathrm{WIND}}$ & $1400 \mathrm{~W}$ \\
Nominal Wind Speed, $\mathrm{V}_{\mathrm{WIND}}$ & $10 \mathrm{~m} / \mathrm{s}$ \\
Rated Rotational Speed, $\omega_{\mathrm{WT}}$ & $300 \mathrm{RPM}$ \\
Damping coefficient, B & $0 \mathrm{Nm} / \mathrm{s}$ \\
Inertia coefficient, $\mathrm{J}_{\mathrm{EQ}}$ & $4 \mathrm{~kg} \cdot \mathrm{m}^{2}$ \\
Stator phase resistance, $\mathrm{R}_{\mathrm{S}}$ & $0.005 \mathrm{ohm}$ \\
Stator d-axis Inductance, $\mathrm{L}_{\mathrm{d}}$ & $7.552 \mathrm{Mh}$ \\
Stator q-axis Inductance, $\mathrm{L}_{\mathrm{q}}$ & $8.348 \mathrm{mH}$ \\
Magnets flux Linkage Constant, $\lambda_{0}$ & $0.34458 \mathrm{~Wb}$ \\
\hline
\end{tabular}

Table 3. Power electronics systems parameters

\begin{tabular}{|c|c|}
\hline Parameter & Value \\
\hline Switching frequency of all converters, $\mathrm{F}_{\mathrm{SW}}$ & $1980 \mathrm{~Hz}$ \\
\hline Line to line RMS Grid Voltage, $\mathrm{V}_{\mathrm{GRID}}$ & $220 \mathrm{~V}$ \\
\hline DS Bus upper limit, $\mathrm{V}_{\mathrm{DC}(\mathrm{MAX})}$ & $380 \mathrm{~V}$ \\
\hline DS Bus lower limit, $V_{\text {DC(MIN) }}$ & $330 \mathrm{~V}$ \\
\hline Injected $\mathrm{AC}$ current control adjustment, $\Delta \mathrm{i}_{\mathrm{ac}}$ & 0.05 \\
\hline IBC Inductors, $\mathrm{L}_{1}$ and $\mathrm{L}_{2}$ & $1 \mathrm{mH}$ \\
\hline DC Bus capacitor, $\mathrm{C}_{\mathrm{DC}}$ & $3 \mathrm{mF}$ \\
\hline Grid Line frequency, $F_{\text {nom }}$ & $60 \mathrm{~Hz}$ \\
\hline
\end{tabular}

With the help of MATLAB/Simulink, the solar array and wind turbine system coupled to the PMSG generator are designed and modelled, as illustrated in Figure 3. Hybrid power system components include a three-phase breaker, inductance matrix transformer (two windings), three-phase V-I measurement, and distributed parameters line. Figure 4 shows the $\mathrm{X}$-axis representing time and the $\mathrm{Y}$-axis representing Vdc (V). This graph also depicts the injection of AC current into the lattice as well as various DC bus voltages. Figure 5 shows the $\mathrm{X}$-axis representing time and the $\mathrm{Y}$-axis representing $\mathrm{Vdc}(\mathrm{V})$. This graph also depicts the injection of AC current into the lattice as well as various DC bus voltages. The simulation results were compared to the performance parameters and the estimated values for those parameters.

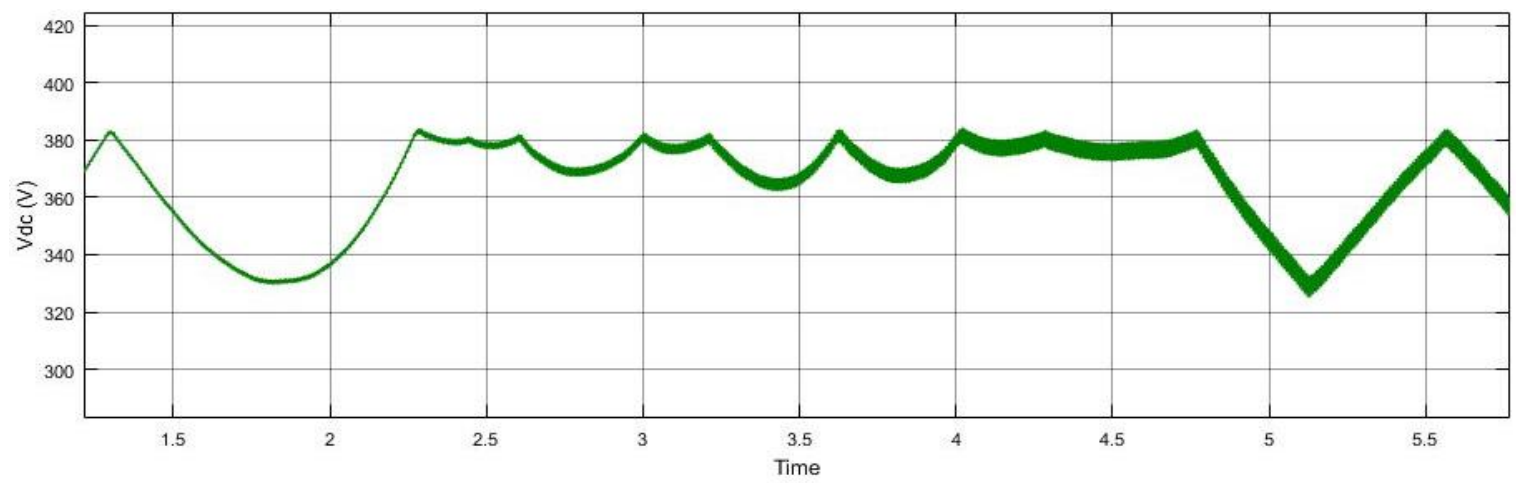

Figure 4. Injected AC current into the lattice and variety of DC bus voltage

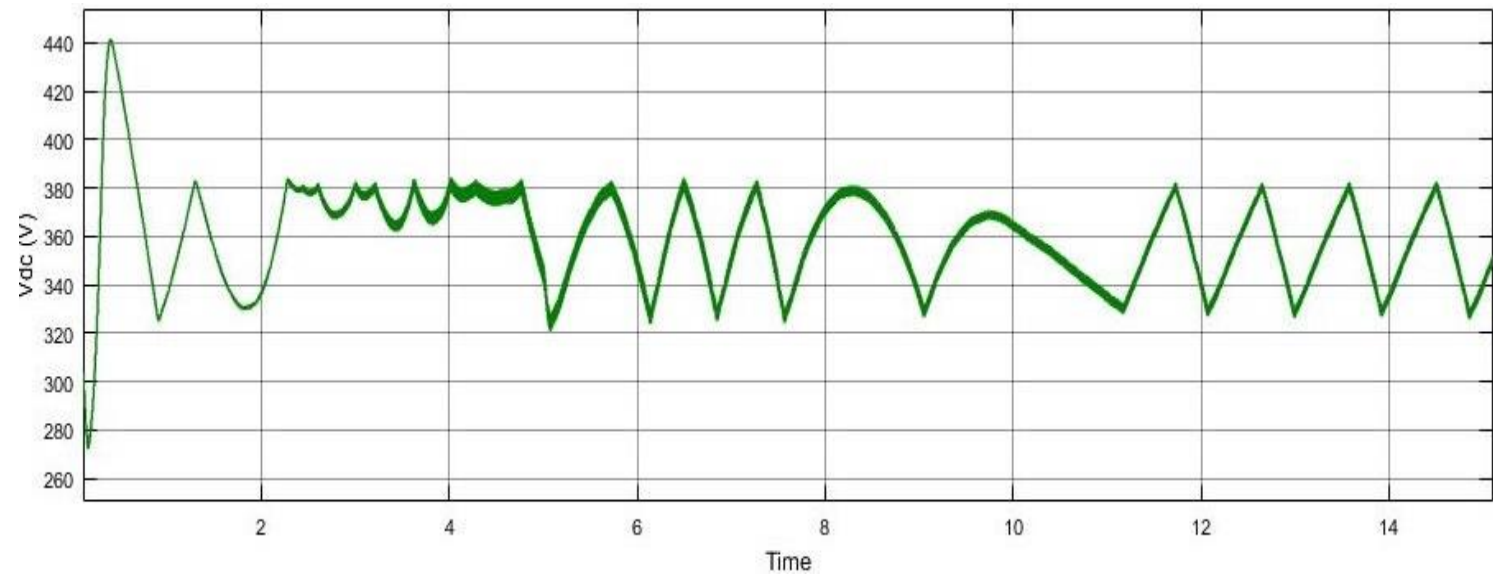

Figure 5. Injected AC current into the lattice and variety of DC bus voltage

Figure 6 shows the $\mathrm{X}$-axis representing time and the $\mathrm{Y}$-axis representing $\mathrm{Vdc}(\mathrm{V})$. This graph also depicts the injection of alternating current into the grid as well as various DC bus voltages. Figure 7 shows the $\mathrm{X}$-axis representing time and the $\mathrm{Y}$-axis representing $\mathrm{Vdc}(\mathrm{V})$. This graph also depicts the injection of alternating current (AC) electricity into the frame as well as numerous DC power suppliers. The outcomes of 
imitation are compared to performance characteristics, and the relevant values are computed. This technique is evaluated based on a comparison of the PV-wind hybrid system's performance characteristics with simulation results. Comparison of the simulation and physical prototypes in the literature with the findings gained through the framework reconstruction.

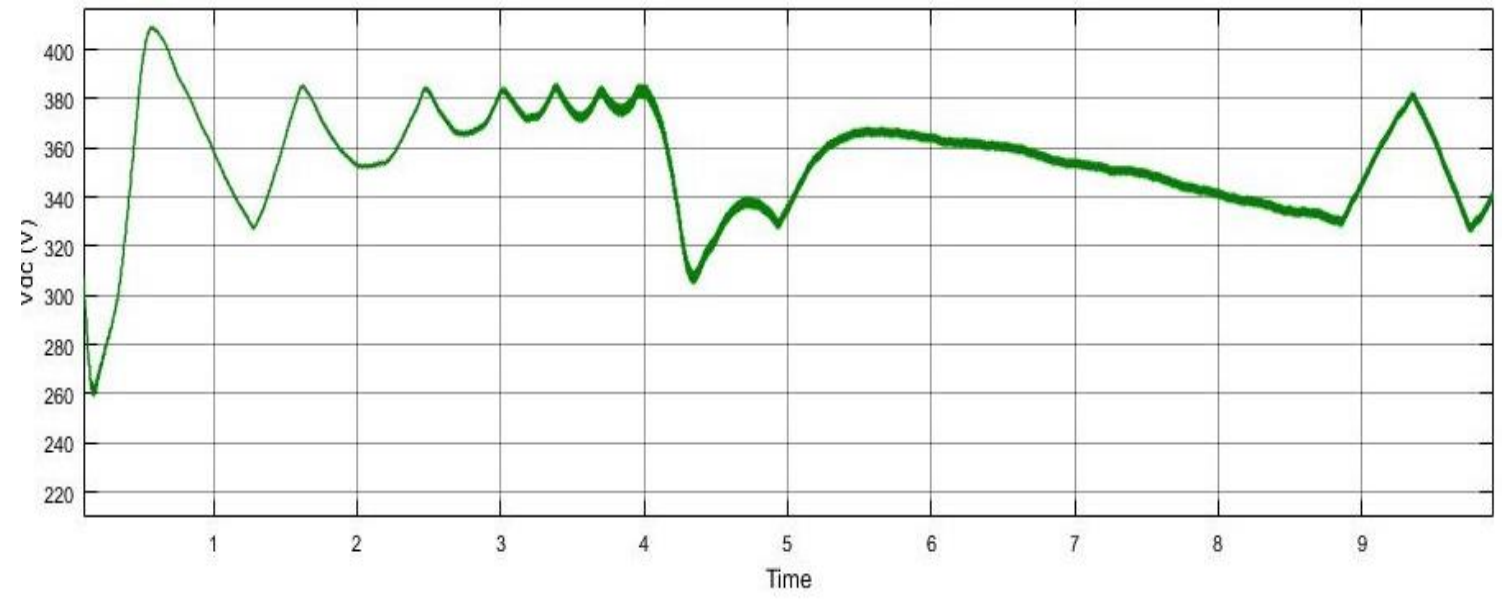

Figure 6. Injected AC current into the grid and variation of DC bus voltage.

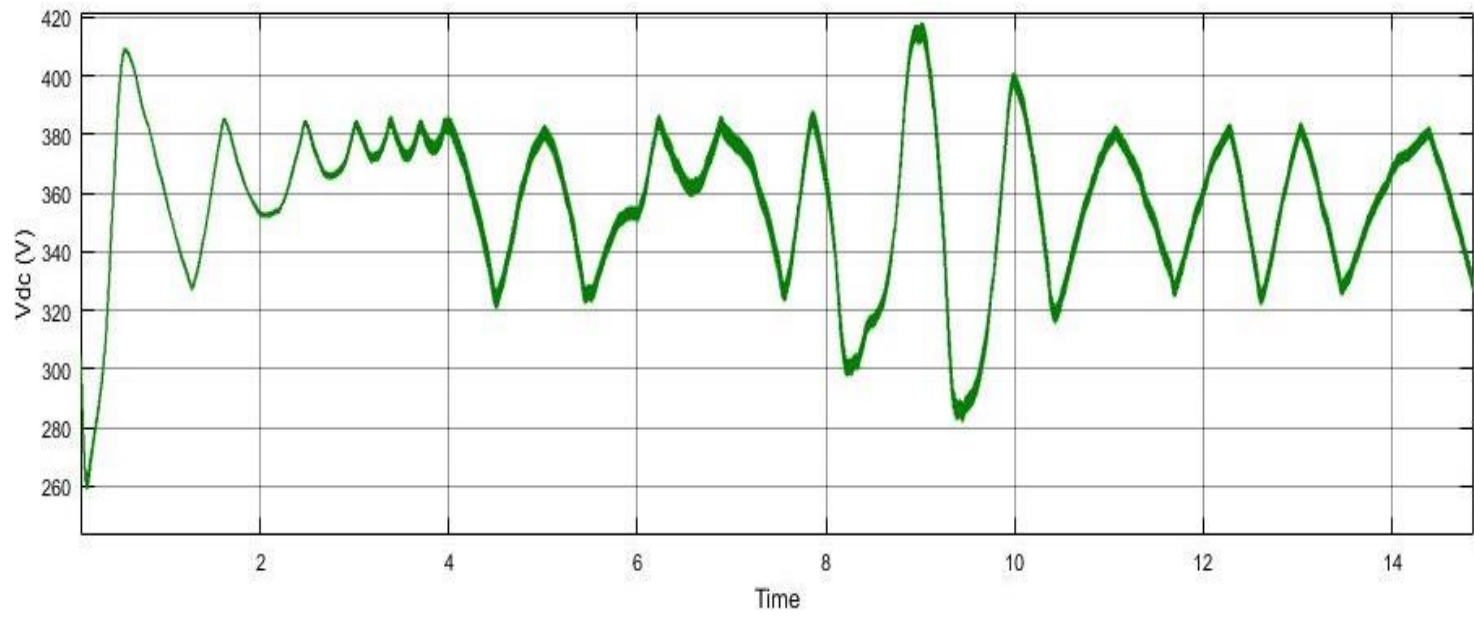

Figure 7. Injected AC current into the framework and variety of DC bus voltage.

\section{CONCLUSION}

The purpose of this work was to focus on dealing with wind power and PV power in the same converter. The main focus was on proving the effectiveness of the hybrid power generation system and presenting it as the best and most efficient alternative to conventional energy sources. This paper worked on all aspects so that the energy used in the production process would lead to a reduction in transfer losses and costs. These resources can reach areas that the government cannot afford. The more creative model offers an amazing asset in real works. The results obtained from the framework recreation are compared with the results of simulation and physical prototypes found in the text. Climate weather information can be provided as information, and segment parameters, such as problems and offline, can also be modeled. Future work will incorporate developmental components into the actual use of climate and model construction to be approved.

\section{ACKNOWLEDGEMENTS}

This research work was funded by "Woosong University's Academic Research Funding-2021". 


\section{REFERENCES}

[1] B. K. Bala and S. A. Siddique, "Optimal design of a PV-diesel hybrid system for electrification of an isolated island-Sandwip in Bangladesh using genetic algorithm," Energy for Sustainable Development, vol. 13, no. 3, pp. 137-142, September 2009, doi: 10.1016/j.esd.2009.07.002.

[2] I. A. Adejumobi, S. G. Oyagbinrin, F. G. Akinboro, and M. B. Olajide, "Hybrid Solar and Wind Power: An Essential for Information Communication Technology Infrastructure and people in rural communities," IJRRAS, vol. 9, no. 1, pp. 130-138, October 2011.

[3] J. A. Baroudi, V. Dinavahi, and A. M. Knight, "A review of power converter topologies for wind generators," Renewable Energy, vol. 32, no. 14, pp. 2369-2385, November 2007, doi: 10.1016/j.renene.2006.12.002.

[4] W. Li and X. He, "Review of Nonisolated High-Step-Up DC/DC Converters in Photovoltaic Grid-Connected Applications," IEEE Transactions on Industrial Electronics, vol. 58, no. 4, pp. 1239-1250, April 2011, doi: 10.1109/TIE.2010.2049715.

[5] A. Singh, R. Krisham, and Y. Sood, "Modeling and Control of Grid Connected Variable Speed PMSG Based Wind Energy System," Conference on Advances in Communication and Control Systems, Mumbai, India, April 2013, pp. 134-139.

[6] J. Hui, A. Bakhshai, and P. K. Jain, "A hybrid wind-solar energy system: A new rectifier stage topology," 2010 Twenty-Fifth Annual IEEE Applied Power Electronics Conference and Exposition (APEC), 2010, pp. 155-161, doi: 10.1109/APEC.2010.5433678.

[7] A. Raj and S. S. Dash, "Grid connected hybrid energy system with Maximum power point tracking technique," 2013 International Conference on Energy Efficient Technologies for Sustainability, 2013, pp. 338-342, doi: 10.1109/ICEETS.2013.6533406.

[8] R. Rajesh and M.M. Carolin, "A comprehensive review of photovoltaic systems," Renewable and Sustainable Energy Reviews, vol. 51, pp. 231-248, November 2015, doi: 10.1016/j.rser.2015.06.006.

[9] A. D. Spera, et al, "Wind Turbine Aerodynamics," Wind Turbine Technology: Fundamental Concepts of Wind Turbine Engineering, 2nd ed, Ed. ASME, pp. 281-412, 2009

[10] Z. Chen, J. M. Guerrero, and F. Blaabjerg, "A Review of the State of the Art of Power Electronics for Wind Turbines," IEEE Transactions on Power Electronics, vol. 24, no. 8, pp. 1859-1875, August 2009, doi: 10.1109/TPEL.2009.2017082.

[11] Y. Xia, K. H. Ahmed and B. W. Williams, "A New Maximum Power Point Tracking Technique for Permanent Magnet Synchronous Generator Based Wind Energy Conversion System," IEEE Transactions on Power Electronics, vol. 26, no. 12, pp. 3609-3620, December 2011, doi: 10.1109/TPEL.2011.2162251.

[12] A. Rolan, A. Luna, G. Vazquez, D. Aguilar, and G. Azevedo, "Modeling of a variable speed wind turbine with a Permanent Magnet Synchronous Generator,” 2009 IEEE International Symposium on Industrial Electronics, 2009, pp. 734-739, doi: 10.1109/ISIE.2009.5218120.

[13] N. Smith and R. McCann, "Analysis and simulation of a multiple input interleaved boost converter for renewable energy applications," 2014 IEEE 36th International Telecommunications Energy Conference (INTELEC), 2014, pp. 1-7, doi: 10.1109/INTLEC.2014.6972129.

[14] G. Bekele and B. Palm, "Feasibility study for a standalone solar wind-based hybrid energy system for application in Ethiopia," Applied Energy, vol. 87, no. 2, pp. 487-495, February 2010, doi: 10.1016/j.apenergy.2009.06.006.

[15] G. M. Tina and S. Gagliano, "Probabilistic modelling of hybrid solar/wind power system with solar tracking system," Renewable Energy, vol. 36, no. 6, pp. 1719-1727, June 2011, doi: 10.1016/j.renene.2010.12.001.

[16] H. Yang, Z. Wei, and L. Chengzhi, "Optimal design and technoeconomic analysis of a hybrid solar-wind power generation system," Applied Energy, vol. 86, no. 2, pp. 163-169, February 2009, doi: 10.1016/j.apenergy.2008.03.008.

[17] G. J. Dalton, D. A. Lockington, and T. E. Baldock, "Feasibility analysis of stand-alone renewable energy supply options for a large hotel," Renewable Energy, vol. 33, no. 7, pp. 1475-1490, July 2008, doi: 10.1016/j.renene.2007.09.014.

[18] M. J. Khan and M. T. Iqbal, "Pre-feasibility study of standalone hybrid energy systems for applications in Newfoundland," Renewable Energy, vol. 30, no. 6, pp. 835-854, May 2005, doi: 10.1016/j.renene.2004.09.001.

[19] F. Blaabjerg, R. Teodorescu, M. Liserre, and A. V. Timbus, "Overview of Control and Grid Synchronization for Distributed Power Generation Systems," IEEE Transactions on Industrial Electronics, vol. 53, no. 5, pp. 13981409, October 2006, doi: 10.1109/TIE.2006.881997.

[20] A. K. Abdelsalam, A. M. Massoud, S. Ahmed, and P. N. Enjeti, "High-Performance Adaptive Perturb and Observe MPPT Technique for Photovoltaic-Based Microgrids," IEEE Transactions on Power Electronics, vol. 26, no. 4, pp. 1010-1021, April 2011, doi: 10.1109/TPEL.2011.2106221.

[21] M. Regad, M. Helaimi, R. Taleb, A. M. Othman, and H. A. Gabbar, "Control of hybrid power system based renewable energy generations using PID controller," International Journal of Power Electronics and Drive Systems (IJPEDS), vol. 11, no. 4, pp. 1775-1784, December 2020, doi: 10.11591/ijpeds.v11.i4.pp1775-1784.

[22] M. I. Hlal, V. K. Ramachandaramurthya, S. Padmanaban, H. R. Kaboli, A. Pouryekta, and T. A. R. T. Abdullah, "NSGA-II and MOPSO based optimization for sizing of hybrid PV/wind/battery energy storage system", International Journal of Power Electronics and Drive Systems (IJPEDS), vol. 10, no. 1, pp. 463-478, March 2019, doi: 10.11591/ijpeds.v10.i1.pp463-478.

[23] A. L. Bukar, C. W. Tan, K. Y. Lau, and A. T. Dahiru, "Optimal planning of hybrid photovoltaic/battery/diesel generator in ship power system," International Journal of Power Electronics and Drive Systems (IJPEDS), vol. 11, no. 3, pp. 1527-1535, September 2020, doi: 10.11591/ijpeds.v11.i3.pp1527-1535. 
[24] H. Azoug, H. Belmili, and F. Bouazza, "Grid-connected control of PV-Wind hybrid energy system," International Journal of Power Electronics and Drive Systems (IJPEDS), vol. 12, no. 2, pp. 1228-1238, June 2021, doi: 10.11591/ijpeds.v12.i2.pp1228-1238.

[25] M. Pushpavalli and N. M. J. Swaroopan, "Performance analysis of hybrid photovoltaic/wind energy system using KY boost converter," International Journal of Power Electronics and Drive Systems (IJPEDS), vol. 10, no. 1, pp. 433-443, March 2019, doi: 10.11591/ijpeds.v10.i1.pp433-443.

[26] G. B. A. Kumar, S. Shivashankar, and K. Keshavamurthy, "Design and control of grid-connected solar-wind integrated conversion system with DFIG supplying three-phase four-wire loads," International Journal of Power Electronics and Drive Systems (IJPEDS), vol. 12, no. 2, pp. 1150-1161, June 2021, doi: 10.11591/ijpeds.v12.i2.pp1150-1161.

[27] P. K. Panda, A. Sahoo, A. Samal, D. P. Mishra, and S. R. Salkuti, "Voltage control of AC hybrid microgrid," International Journal of Power Electronics and Drive Systems (IJPEDS), vol. 12, no. 2, pp. 793-802, June 2021, doi: 10.11591/ijpeds.v12.i2.pp793-802.

[28] A. Rahmouni, "Impact of the hybrid reactive power compensator on the power grid used a fuzzy PI regulator," International Journal of Power Electronics and Drive Systems (IJPEDS), vol. 12, no. 1, pp. 170-182, March 2021, doi: 10.11591/ijpeds.v12.i1.pp170-182.

[29] S. R. Das, D. P. Mishra, P. K. Ray, S. R. Salkuti, and A. K. Sahoo, "Power quality improvement using fuzzy logicbased compensation in a hybrid power system," International Journal of Power Electronics and Drive Systems (IJPEDS), vol. 12, no. 1, pp. 576-584, March 2021, doi: 10.11591/ijpeds.v12.i1.pp576-584.

[30] A. S. Ingole and B. S. Rakhonde, "Hybrid Power Generation System Using Wind Energy and Solar Energy," International Journal of Scientific and Research Publications, vol. 5, no. 3, pp. 700-703, March 2015.

[31] S. C. Kim, S. Narasimha, and S. R. Salkuti, "A new multilevel inverter with reduced switch count for renewable power applications", International Journal of Power Electronics and Drive Systems (IJPEDS), vol. 11, no. 4, pp. 2145-2153, December 2020, doi: 10.11591/ijpeds.v11.i4.pp2145-2153.

[32] P. Ray and S. R. Salkuti, "Smart branch and droop controller based power quality improvement in microgrids," International Journal of Emerging Electric Power Systems, vol. 21, no. 6, September 2020, doi: 10.1515/ijeeps2020-0094. 